\title{
La vorágine: Impunity, Memory and Human Rights
}

\author{
Alfredo Duplat / Minnesota State University, Mankato
}

Andrés Molina-Ochoa / South Texas College

One important trend in Colombia's democratic history is the continuous quest to end impunity and guarantee fundamental rights for all its citizens. Today, this process is far from over. According to the United Nation Development Program (UNDP), countries in Latin America "(...) show large deficits in capacities concerning justice and security, which are reflected in alarming levels of impunity, the crises in their prison systems and the feeling of mistrust citizens harbor regarding the institutions of justice and the police" $(2013, v)$. This article proposes that José Eustasio Rivera's intentions in writing La vorágine [1924] are two-fold: he used the novel as a narrative to denounce what we understand as crimes against humanity in Colombia, but more importantly, the novel was conceived as a fictional archive to fight against impunity. As Eduardo Neale-Silva conclusively demonstrated, Rivera worked with a militant mindset and used his novel as a call to improve life conditions of vulnerable communities and protect their civil rights, denounce organized crime and State corruption, and also ask to enforce sovereignty in the jungles in order to prevent future crimes against humanity (1960, Chap. XI). From this perspective, a novel like La vorágine fulfills a social function that echoes the objectives of a human rights legal framework known as the right to the truth. While a variety of definitions of the right to the truth have been suggested, this paper will use in the next section the definition first suggested by Joinet (1997), and later analyzed by Priscilla B. Hayner (2010) and Ciorciari and Fransblau (2014).

\section{Literary Fiction and the Right to the Truth}

Facing state institutions that neglected the prosecution and punishment of crimes against humanity, narrative fiction in Colombia is a privileged source to acknowledge those crimes. A notable example of this connection between impunity, distrust and narrative fiction is Rivera's La vorágine (or The Vortex, as it has been translated into English), arguably the most important novel in Colombia during the first half of the twentieth century. The primary purpose of this essay is to explore how narrative fiction can be understood as a mechanism to fight against impunity.

In the context of human rights studies, the ideal of truth is crucial in the fight against impunity. According to Ciorciari and Fransblau (2014), "the right to the truth invests both individual victims and societies with a right to know the facts surrounding gross human rights violations" (5). For this reason, Louis Joinet "emphasized that 'the right to know implies that archives must be preserved,' and that inventories must be kept, including those of 'relevant archives held by third countries, who shall be expected to cooperate with a view to communicating or restituting archives for the purpose of establishing the truth" (Joinet in Ciorciari and Fransblau, 7). ${ }^{1}$ The rational foundation supporting the necessity of the right to the truth acknowledged that "the realization of the collective right to truth concerning prior abuses in periods of transition, or following periods of conflict, empowers the body politic to educate itself, reform institutions and promote policies that prevent recurrence of past violations" (Open Society Justice in Ciorciari and Fransblau, 68-9). In this sense, the right to the truth operates in theory as a system of checks and balances against crimes committed by civilians or public servants against humanity.

Here we propose that in prominent cases in Colombia, literature has become an alternative to acknowledge crimes against humanity when there are no archives available. This situation is far from extraordinary because one mechanism used by criminals to support structures of impunity is the elimination of any register that may document gross human rights violations. It is not a coincidence that the most important Colombian novels during the twentieth century revolve around crimes against humanity: the rubber boom violence narrated by José Eustasio Rivera in La vorágine - the object of our analysis - and also the Banana Massacre of 1928 narrated by Gabriel García Márquez in One Hundred Years of Solitude. Although the involvement of the State is different in the crimes previously listed, from our perspective the social function of these novels is somehow similar: the use of narrative fictions to fight against impunity (see: Molina-Ochoa and Duplat).

Before proceeding to examine La vorágine it is important to clarify two terms: the right to the truth and impunity. The right to the truth is usually understood in two different senses. In the first sense, it is defined as "several legally enforceable rights that empower next of kin to learn the truth about a family member's fate" (Groome 2011, 3). This also includes the right to demand that States investigate and find the truth of a crime, usually through a criminal process, which is the outcome of a long process that began with the Geneva 
Conventions that guaranteed the right to find the whereabouts of relatives after a war. According to Article 16 of the Geneva Convention, Parties in an International Conflict, "Shall facilitate the steps taken to search for the killed and wounded..." (1949a). In the same sense, article 17 of the same Convention orders each Party to "search for the persons who have been reported missing by an adverse Party" (1949b).

In the second sense, the right to the truth is understood as a right held not by individuals but by society as a whole because it is crucial to "Know the truth about past events, as well as the motives and circumstances in which aberrant crimes came to be committed, in order to prevent recurrence of such acts in the future" (IACHR 2014, § 15, 10). Regarding the collective nature of the right to the truth, the socialization of truth is fundamental in this context. This task is usually performed by truth commissions (see: Hayner 2010).2 Although the rubber boom violence was denounced and explained in detail in several reports and documents before the publication of La vorágine (Lacrimabili Statu [1912], Hardenburg [1912], Paternoster [1913], Thomson [1913]), Rivera's novel was the most effective narrative to socialize those crimes in Colombia. Unless otherwise stated, the second social-minded sense will be used in this paper every time the right to the truth is mentioned.

According to the Inter-American Commission on Human Rights (IACHR), impunity is "the overall lack of investigation, tracking down, capture, prosecution and conviction of those responsible for violating the rights protected by the American Convention" (2014, 36-7). Every time a crime is forgotten we faced the consequences of impunity. The opposite of impunity is accountability. According to Skaar, García-Godos and Collins (2016), accountability is understood as follows:

the explicit acknowledgement by the State that grave human rights violations have taken place and that the state was involved in or responsible for them. Means of accountability can include but are not limited to, the recovery and diffusion of truth, criminal prosecution, reparations, and efforts to guarantee non-repetition (4).

Today Colombians typically remember the slavery and killing of indigenous communities and colonos in the jungles of the Orinoco and Amazon basin during the rubber boom (1879-1912) through the reading of La vorágine (a work of fiction) and not through the official history documented in court papers or news reports. We believe that Rivera's intention was to secure what we understand today as the right to the truth. From this perspective the novel is an alternative repository of truth because it is a narrative that denounces crimes against humanity in the rubber producing areas. These narratives came to be perceived by Colombian readers as the fictional archive that allowed the recognition of those crimes. For us, it is clear that this is not an accidental result.
Rivera wrote the novel in this way because he perceived the Colombian State as an unreliable option to seek accountability and justice related to the heinous crimes committed in the rubber-producing areas.

\section{Fictions of distrust versus impunity}

In Foundational Fictions: The National Fictions of Latin America (1991), Doris Sommer analyzed how literature played a central role in Latin America's nation and state-building process from the wars of independence, until the end of the modernization period in the 1930s. By studying novels from the Republican era, Sommer affirms that the nation-state was responsible for creating a national identity, amongst other means, by the use of national novels, "the ones that governments institutionalized in schools and that are by now indistinguishable from patriotic histories" (1991, 30). In her words, Latin America offers a clear example of "the inextricability of politics from fiction in the history of nation-building" (1991, 5-6). The effects of this alliance are described by Sommer as a "rhetoric for the hegemonic projects in Gramsci's sense of conquering the antagonist through mutual interest, or 'love', rather than through coercion" $(1991,6)$. Sommer builds her perspective based on Benedict Anderson's ideas on nationalism as an "imagined community" (1983). For Sommer, literature provided a foundational fiction to support national power, while the political establishment supplied the necessary readership to promote the formation of national cannons in countries with neither strong cultural markets nor readership. In her words " $[\mathrm{t}] \mathrm{he}$ historical romances became national novels in their respective countries, a term that refers not so much to their market popularity, although to be sure many of these novels were immediately popular, but to the fact that they became required reading by the first decades of the twentieth century" (51). As has been noticed by Lee Skinner, the object of study of Sommer and Anderson "is not Latin American national identity itself, but rather (...) the methods through which national identity is created and consolidated" $(2001,25)$.

For Sommer, it is not a coincidence that all Latin American national novels until the 1920's are love stories. This happens because those novels have the function of resolving social conflicts symbolically through romance. In Sommer's words, "[w] hether the plots end happily or not, the romances are invariably about desire in young chaste heroes for equally chaste heroines, the nation's hopes for productive unions" $(1991,24)$. In these fictions, love connects isolated and frequently opposed social sectors. If history did not provide enough evidence to support the foundational myth for the new Latin American nations, which from Sommer's perspective were exclusively the product of an elitist creole uprising against the Spanish Crown, fictions came to be the second-best solution to support the nation-building process. 
These narratives that suggest synthesis as the basic premise for Latin America's new nations are called by Sommer foundational fictions.

Over the past two decades, two major critiques of Sommer's groundbreaking analysis have allowed a more complete perspective of the role of literature in the nation-building process as well as a new understanding of the nation-building process that avoids a top-down perspective. The first critique seeks an expansion on Sommer's understanding of the dialogue between politics and literature in Latin America. In On the Dark Side of the Archive: Nation and Literature in Spanish America at the Turn of the Century (2010), Juan Carlos González-Espitia inserted non-canonical decadent narratives in the process of nation building in Latin America. González-Espitia analyzed narratives by José María Vargas-Vila, Horacio Quiroga, Clemente Palma, José Martí and Fernando Vallejo to conclude that when these writers problematize the idea of "nation" as a harmonious space, they are in fact participating in a contrario nation-building process. From this perspective, the idea of "nation" is not a monolithic notion but a polyphony where other voices are also participating in the process.

The second critique is a reassessment of Sommer's historical framework based on Anderson's definition of nation as an imagined community. The intention of this multidisciplinary corpus of essays is clear from its title, Beyond Imagined Communities: Reading and Writing the Nation in Nineteenth-century Latin America

(2003). This collection of essays edited by Sara CastroKlarén and John Charles Chasteen still praises Anderson's perspectives on the process of nation formation as a "social construction, rather than as a primordial fact" (Chasteen 2003, XXI), but also seeks to correct both Anderson's chronology and proposed causality when he builds his case for Latin America. For Chasteen, understanding the formation of Spanish American nations has "something to do with Creole's social world as imagined by Anderson before independence, but also with economic, political, and military concerns [...] that Anderson disregards utterly" (XX).

As has been noted by Gabriela Nouzeilles, Beyond Imagined Communities "embraces what Eric Hobsbawn and Ernest Gellner called the modernist position among existing theories of nationalism" $(2005,514)$. From this perspective, nations are a product of modernity, constructed by elites, and they are the result of nationalist projects. However, a new corpus of research put into question the overarching power of the elite class in the nation building process in Latin America. In the case of Colombia, Contentious Republicans (2004) by James E. Sanders, and Myths of Harmony (2007) by Marixa Lasso present sound arguments to shift the focus from the elite class to the participation of different groups-like Afro-Colombians - in the national project. Sanders clearly explains the limitations of the top-down perspective promoted by the modernist position on nationalism with these words:

Traditional literature concerning nineteenth-century Colombian politics suggest that subalterns were politically ignorant, indifferent, or, simply, the clients of powerful patrons. This approach - besides excluding plebeians from history and denying them agency - fails to explain the astonishing variety of subaltern political action and discourse in the nineteenth century and elite's continual efforts to come to terms with subaltern politics. Such assumptions also ascribe a power to elites that, at least in Colombia, they simply did not possess. (2)

In fairness, today we have the advantage to benefit from a broader perspective on the nation-building process in Latin America to evade the insightful but totalizing perspective proposed by Anderson and Sommer. Without any doubt $L a$ vorágine has an important role shaping Colombians' perspectives on their own nation-building process. But for us reading Rivera's book as a "fiction of distrust" offers us a more strategic angle to understand the social function of this novel in Colombia.

If we read the novel in its own historicity, La vorágine seems to incorporate Rivera's political agenda. According to Neale-Silva, this agenda was composed of six items:

1. defender la soberanía nacional (...);

2. garantizar la paz de los colonos por medio de un sistema gubernamental respaldado por contingentes del ejército;

3. remover los comisarios y autoridades menores que hubiesen dado pruebas evidentes de incapacidad administrativa;

4. exigir la libre navegación de los ríos en que desembocan las vías fluviales colombianas;

5. poner al país en estado de alerta en todo lo relacionado con la Casa Arana e

6. iniciar (...) la magna obra de redención de tierras nacionales hasta entonces olvidadas. $(1960,285)$

Following Neale-Silva's perspective, Rivera as a member of the Centennial Generation was invested in making the Colombian state a better version of itself. In other words, Rivera seems to be the ideal public servant as a member of the House of Representatives, and an ideal patriot as a reformist. However, Rivera's novel is also the result of the exhaustion of its own idealism. Neale-Silva traced Rivera's experience as a member of the House from 1922 and concluded that by 
December 30 of 1923: "el poeta se sentía sin apoyo moral, desconcertado. Una profunda desilusión le acosaba en todo momento y le hacía más acerbo el recuerdo de sus aspiraciones" (273). The source of Rivera's depression is the reluctance of his colleagues of the judicial branch, and of high officials of the executive branch, to consider his petitions to increase the presence of the State in the rubber-producing areas.

From our perspective, La vorágine expresses Rivera's disillusions in the administrative capacity of the Colombian government to enforce complete sovereignty in the rubber-producing areas. In this sense, the novel is a fiction of distrust, because the performance of Colombian State institutions in the region goes from dystopian to absent. Its narrative also seeks a concrete intervention from society to reject the impunity that results from the absence of the State in the region. Because the novel was acclaimed as the most important narrative work of its time, and soon became part of the Latin American canon, La vorágine was eventually incorporated as a compulsory reading into the Colombian educational system. ${ }^{3}$ This trajectory explains how this national novel was able to fulfill a social function that echoes the objectives of the right to the truth.

Ninety-six years after the publication of La vorágine, the idea of enforcing the state of law over the whole national territory is not completed in Colombia. One may think that the novel is still a "fiction of distrust" not just because the Colombian government failed to enforce complete sovereignty in 1923 but also because today the Colombian government has yet to fulfill this mission.

\section{La vorágine as fiction of distrust}

The novel narrates the misfortunes of Alicia, a teenager, and Arturo Cova, apparently a promissory poet, both living in Bogota at the beginning of the twentieth century. The couple starts a secret affair, and when Alicia's family discover it, they decide to force her into a marriage with a wealthy old widower. The lovers run away into the plains; the scandal erupts in Bogotá, and the police accuse Cova of kidnapping.

The couple finds refuge in an isolated place relatively close to the jungle, and the initial adventure becomes a nightmare. When Alicia finds out she is pregnant, Arturo becomes rude and despotic. For this reason, Alicia accepts the offer of a Machiavellian rubber merchant, Narciso Barrera, to go with him into the jungle. She goes hoping to end her relationship with Arturo, and also seeking autonomy. But Barrera's real plan is to sell Alicia as a sex slave in a brothel for rubber workers. Arturo goes after her, and dreams to build a family with Alicia after killing the merchant.
Arturo goes to the jungle looking for Alicia and inevitably falls into a downward spiral of misfortunes. In this process he also discovers how the rubber is harvested as well as the required systematic violence that maximizes profits in this international business. He realizes that the rubber companies are mistreating and killing entire indigenous communities and enslaving humble peasants or colonos that do not count on any type of support from the Colombian State. Arturo feels an outburst of indignation when he understands that there is no justice available for the victims of the rubber market. All of them are isolated, and for this reason, invisible and ignored by the State and Colombian society. Arturo finally finds Alicia and kills Barrera. In the end, Alicia gives birth to a premature child and the couple tries to escape from the jungle, but they disappear in the process and "are devoured by the jungle" (as the novel's final sentence- "se los tragó la selva"-indicates).

When La vorágine was first published in 1924, Rivera was a lawyer, and as we commented earlier had been a legislator in the House of Representatives for the Conservative party since 1922. As a Congressman, Rivera had denounced the Colombian State's lack of presence in the jungles where the rubber production was capitalized by companies from Peru, Brazil, England and Colombia, at the cost of violations of human rights, and through the systematic use of violence, and even slavery, against Colombian farm laborers, or colonos, and indigenous people (Neale-Silva 1960, Chap. XI).

Due to his professional trajectory, Rivera was an expert on the crimes associated with the production of rubber for two reasons. First, he knew the region better than the majority of the political elite based in Bogotá. Before graduating with his Juris Doctorate in 1917, Rivera wrote a thesis on land property rights in the region of Casanare where he lived for a year, an area that, although is not close to the rubber-producing areas in the jungle, had more contact with the realities of the rubber market operation than the capital and center of power in Colombia, Bogotá. ${ }^{4}$ It was in this capacity when Rivera started to understand why the businesses around the rubber-producing areas were problematic in terms of national security, and also in terms of a lack of legal protections for Colombians in the region.

The second reason is also important: Rivera was appointed by the House of Representatives of Colombia to supervise the demarcation of the border line between Colombia and Venezuela during 1922 and 1923. It was during this time that Rivera experienced first-hand the scope of the crimes promoted by the rubber companies in the region. When he came back to the capital after a very tortuous journey, he was able to predict, in 1924, an invasion of Peruvian troops into Colombia's rubber-producing areas that eventually happened between 1932 and 1933 (1924c, 1924d, 1924a, 1924b). ${ }^{5}$ 
Although, Rivera tried to explain the severity of these crimes, as well as how dangerous this situation was in terms of sovereignty for Colombia, his interventions in the House of Representatives, as well as his letters published in the most prestigious liberal national newspapers of his time, El Tiempo and El Espectador, were largely ignored in Colombia. The political elite class read Rivera's interventions as an overreaction (Neale-Silva, Chap. XI). Rivera also tried to mobilize a group of political allies and worked to create a grass roots movement to publicly denounce acts of violence promoted by the rubber market, but the breadth and scope of these interventions fell short in his attempt to change status quo. ${ }^{6}$ From this perspective, the historical importance of La vorágine as a fiction of distrust in Colombia is its capacity to make the atrocities related to the rubber boom visible to a critical mass of readers. It is not an overstatement to argue that the crimes committed in the rubber-producing areas in Colombia are part of the nation's memory, thanks to Rivera.

In Colombia, rubber-producing areas were located in the jungles around the Amazon, Orinoco, and Putumayo rivers, in the south and southwestern parts of the country. This is an isolated border area next to Venezuela, Brazil, and Peru. The characteristic illegality surrounding the rubber business was not a small or new phenomenon in Colombia when Rivera wrote La vorágine. The first formal complaint against rubber companies appeared in 1891 (Neale-Silva 1960, 280). At the beginning of the twentieth century, the systematic brutality of the rubber companies against indigenous population in the jungles were of public knowledge in the adjacent regions, but completely ignored by the central authorities in Colombia, Peru and Brazil. In June of 1912 the Pope Pious X published the encyclical Lacrimabili Statu denouncing the same situation (2020). From 1911 to 1913 there are at least four serious reports, some of them compiling several documents denouncing the same type of illegal activities, written by local authorities in Peru and Colombia, and also by international observers.

From those reports, three books were published in English in 1913 to spread the news and stop the international complacency regarding those crimes. Their titles are self-descriptive: The Putumayo, the Devil's Paradise by Walter Ernest Hardenburg (2017), The Lords of the Devil's Paradise by G. Sidney Paternoster (1913), and The Putumayo Redbook by N. Thompson (2019). The last book mentioned was the best-known report at the time. It contains the testimonies by Benjamín Saldaña Roca. According to Neale-Siva, Rivera read these testimonies as well as another important collection of testimonies, chronicles and denunciations written by Judge Carlos Valcárcel (286). None of the mentioned reports stopped the violence committed by the rubber companies. When Rivera visited the region, he understood the scope of the atrocities reported decades earlier.
Neale-Silva offered several hints to reconstruct Rivera's impressions from this travel; for example, his experiences in San Fernando de Atabapo are particularly telling:

¿Para qué le servían sus conocimientos jurídicos? En una tierra en la que no había instituciones, ni más ley que la fuerza, hablar del código civil o criminal resultaba a la vez pueril y grotesco. Cosa curiosa: aquí la fama la tenían monopolizada, al parecer, los facinerosos. Y entre éstos nadie más famoso que el finado coronel Tomás Funes. (238)

The dimensions of these crimes are difficult to determine. But there are enough testimonies and historical evidence to ascertain that the situation was of extreme gravity and urgency. Between 1879 and 1912, indigenous nations in the jungles of the Orinoco and Amazon basins were enslaved and massacred during the rubber boom. Julio César Arana, a Peruvian citizen, was the main rubber baron in the Amazon basin at the beginning of the twentieth century and also the main agent responsible for crimes against humanity in the region. His rubber trading company was known in the region as the Casa Arana. ${ }^{7}$ Although the production of rubber decreased during World War I, the violence against indigenous communities continued during the 1920s, as Wade Davis indicates:

As the Indians died, rubber production soared. In 1903 the Putumayo yielded 500,000 pounds. Two years later the figure was over a million. In 1906, at a time when even the scrapings of the tin cups attached to the trees to collect latex fetched a price, the output rose to 1.4 million pounds. In the twelve years that Arana operated on the Putumayo he exported over 4,000 tons of rubber, earning more than $\$ 7.5$ millions in the London market. During that time the native population on the Putumayo fell from over fifty thousand to less than eight thousand. For each ton of rubber produced, ten Indians were slaughtered, and hundreds left scarred for life with the welts and wounds that became known throughout the Northwest Amazon as la marca arana, the mark of Arana (1996, 239).

With the expansion of the automotive industry at the beginning of the twentieth century, rubber became a strategic global commodity. For this reason, Henry Ford had the epiphany to industrialize the jungle and establish efficient rubber plantations. As Greg Grandin reports in his book Fordlandia: The Rise and Fall of Henry Ford's Forgotten Jungle City, the Washington Post praised Ford's project because it was "intending to cultivate not only 'rubber but the rubber gatherers as well"” (2009, 5). Unfortunately, Ford missed a basic point: a tropical jungle is not a place fit for plantations. The rubber trees grew up naturally in random locations and, in order to harvest them, it was necessary to find them and extract the natural rubber on-site. This process required 
intensive manual labor and it is not, by any means, an efficient process.

The reports that Carl D. LaRue made for Ford are both shocking and heart-wrenching. Grandin summarizes LaRue observations in the following terms:

The real lords of the rubber trade, LaRue told his boss, were the foreign-owned export houses and financial firms, which were 'utterly heartless toward their victims.' Because of their monopoly, they paid next to nothing to the traders who floated the latex downriver to Belém. Of these foreign interests, LaRue singled out the British as being particularly indifferent to the value of human life. $(2009,91-2)$

As was pointed out in the opening section of this essay, it is clear to us that Rivera designed La vorágine as a fictional archive to fight against impunity. Let us now examine the evidence to support this argument. In La vorágine, Arturo Cova is the center of the text because he is the narrator and main character. Arturo Cova is narcissistic, selfish, racist, elitist, impulsive, sometimes irrational and also a misogynist person with hints of remorse at the end of the story. Monserrat Ordóñez rightly pointed out this peculiarity as the main formal characteristic of the novel, that she describes as a "broken voice." According to her the contradictory and unpredictable nature of Arturo Cova is one of the narrative strategies in La vorágine - a narrative that reproduced the medieval perspectives and unspeakable violence performed by the Spanish Conquerors after the so-called "discovery" of America $(1995,21-5)$.

Cova, a man from the city, seems to be destined to lose his mind in the jungle. This narrative strategy sanitizes the frontal critique that portrays the novel against the incapacity of the Colombian State to control its whole territory. The level of unspeakable violence portrayed in the novel was perceived as the literary expression of Cova's unstable mental capacity. Rivera lamented this perception in 1926, when he wrote:

Dios sabe que al componer mi libro no obedecí a otro móvil que al de buscar la redención de esos infelices que tienen la casa por cárcel. Sin embargo, lejos de conseguirlo, les agravé la situación, pues sólo he logrado hacer mitológicos sus padecimientos y novelescas las torturas que los aniquilan. "Cosas de La Vorágine", dicen los magnates cuando se trata de la vida horrible de nuestros caucheros y colonos de la zona amazónica. Y nadie me cree, aunque poseo y exhibo documentos que comprueban la más inicua bestialidad humana y la más injusta indiferencia nacional (Pérez Silva 1981, 108).

In a clear twist of Rivera's intentions, the novel was read not as a patriotic denunciation but as something else. For example, trying to establish when and how $L a$ vorágine became a mandatory reading in Colombian schools, we found an official report written by the secretary of education of the Department of Nariño in 1938 affirming that the novel was one of the favorite adventure books for children between 10 and 12 years old in the public school system (AGN 1938).

Since its publication, the critical reception of La vorágine has been a point of contention. As Silvia Molloy comments, this novel traditionally has been the object of disdain for several critics at the level of its fabula or narrative construction. In 1926, Luis Trigueros complained about what he saw as a lack of narrative structure:

Las fabulaciones de Rivera -hay que reconocerlo- carecen de método, de orden, de hilación: $L a$ Vorágine, pongo por caso, es un caos de sucesos aterrantes, una maraña de escenas inconexas, un confuso laberinto en que los personajes entran y salen, surgen y desaparecen sin motivos precisos ni causas justificativas (Pérez Silva 1981, 95).

Years later, Mario Vargas Llosa defined the novel as just an antecedent, a work that does not contribute to the qualitative change that the Latin American narrative underwent since the postwar period (1972, 130-31). More recently, Ericka Beckman also complains about the same lack of clarity:

Through a confusing mixture of Cova's first-person narrative and indirect free discourse, characters tell harrowing stories of the rubber economy, which revolve around forced advances of provisions to keep workers in debt (debt peonage) and outright slavery. Characters also tell of the perverse cruelty visited on the rubber workers, especially the indigenous inhabitants of the jungle. (Beckman 2013, 163)

However, for critics like Molloy, the narrative complexity of the novel deserves at least an honorary mention (1987, 745-46). As Silvia Benso argues in perhaps the most comprehensive analysis of the fabula of La vorágine, Rivera builds his novel as a collection of narratives developed by five different narrators (1975). We believe that Rivera purposely used the idea of testimony to write La vorágine as understood from a legal perspective. Every narrator in his novel is considered a witness. Their voices are built as evidence that make the case to denounce heinous crimes in the rubber-producing areas. Justice is absent in the novel, because the Colombian State is also absent from these territories. For this reason, the reader must function as a kind of judge. In the end, it is the reader who must make sense of every individual narrative to put together a cohesive story.

In this regard, Alfonso Arocha analyzes the narrative structure of La vorágine as the written result of a testimonial rhetoric. He defines testimonial rhetoric as "la estrategia 
discursiva con la cual el narrador se esfuerza por hacernos entender que lo narrado no es producto de la ficción, sino producto de una realidad social presenciada y vivida por él" $(2007,133)$. For us, it is clear that the fragmentary nature of the novel at the level of its fabula is the result of a calculated effect with a clear political agenda in mind: the creation of a fictional archive with multiple testimonies to denounce human rights violations in the jungle.

Similar to what happens in a truth commission, the ending result of the investigation is a loosely packed collection of testimonies from survivors or persons of interest that helps us understand the modus operandi behind serious crimes. One cannot read a collection of testimonies with the same expectations that one reads a novel. La vorágine is chaotic because it was conceived as a collection of testimonies, and in this sense, the novel operates as an archival alternative to understand the causes and consequences of violence in the rubber-producing areas.

As we have already commented, the most important narrator, and also the main character in La vorágine, is Arturo Cova. The reader knows that Cova started his journal when he was close to finding Alicia in the jungle. In this sense, Cova's narrative solidifies the memory of traumatic events. It works as a fictionalized testimony and also contains testimonies of allies that Cova finds in the jungle.

Additionally, Cova's narration compiles testimonies from other important characters cum narrators. Helí Mesa gives his testimony in the second section of the novel, when he describes the slavery suffered by colonos and indigenous people in the jungle. Clemente Silva's testimony also appears in the second section, and tells of his experiences in the jungle, the human degradation that he suffers while he is harvesting rubber, and how he is sold as a slave twice in the jungle. The last testimony contained in Cova's memory is provided by Ramiro Estévanez in the third section. This testimony is different because it presents the systemic perspective of the criminal modus operandi used by powerful people to control the rubber market in the jungle. Estévanez focuses on the historical figure (and one of the most powerful men in the jungle on the Venezuelan side), General Tomás Funes, who is called the Colonel in the novel. He is the main agent responsible of heinous crimes against humanity in this region between 1908 and 1921, and Governor of the State of Amazonas in Venezuela between 1913 and 1921. Rivera builds Estévanez's testimony, as well as Cova's opinion, to explain the rationale supporting systemic violence in the region.

It is evident that Rivera's personal experiences and frustrations with the central government, and the lack of capacities of the nation-state are a central topic in La vorágine. The thesis of the novel in this regard is that the vacuum of power produced by the weakness of the State is an incubator where criminal structures can prosper easily. The rubber was a legit product, but not the way it was produced. The conditions that promoted such horrendous levels of violence portrayed in the novel are normalized in the region because the State was absent, and criminal structures promoted by rubber barons became a de facto government in the jungle.

But there are more instances where the corruption of public servants is described in absolute clear terms. There are three specific descriptions of public servants of all levels in the novel, and all of them are negative. The first one is the description of Pepe Morillo Nieto, better known as 'el Pipa.' At the beginning of the story, el Pipa is the commissary of Cáqueza. In a dialogue with Cova, el Pipa tells the story of how he became the commissary. First, he was fairly accused of stealing livestock, but his godfather was the mayor of the town and instead of sending him to jail, he appointed him as commissary. The next morning, Cova discovers that el Pipa stole his horse and saddle.

The next public servant is the General Gámez y Roca, the Commander in Chief of the Army in Villavicencio. Gámez y Roca is described as an alcoholic pervert who threatens Cova with jail if he refuses to give him Alicia as his personal mistress. In this incident, Gámez y Roca is drunk and sexually harasses Alicia in front of Arturo. For this reason, Arturo takes one of Alicia's shoes and attacks Gámez y Roca until he is knocked out on the floor.

The third example is the judge from Orocué, José Isabel Rincón Hernández. The situation in which Cova encounters this judge is quite comical. The judge is lost in a desolate area while he is looking for Cova. When the judge's assistant sees Cova, he asks for help because "the justice is lost." And Cova's friend, a native of the plains, bluntly answers "justice has been lost forever."

\section{Conclusion}

In the writing process of $L a$ vorágine, we see a pattern that, decades later, was repeated by human rights activists in Latin America, and that eventually led to the recognition of the right to the truth. First, there is a series of atrocious crimes committed by the State or facilitated by its absence. Second, there is an attempt by perpetrators and accomplices to use their power and the State to make people forget about the atrocities committed, and to guarantee a complete impunity. Third, there is an attempt by victims or interested persons to find justice, or at least some recognition of the crimes committed. In the case of La vorágine, Rivera's writing is an alternative to the third step because the crimes narrated are part of Colombia's national memory thanks to this novel.

We align our analysis with Amanda Smith's perspective, when she explains "that Rivera's narrative representation of 
the jungle in La vorágine exposes Colombia's maps as a kind of fiction themselves, a cartographic illusion, that nevertheless causes devastating consequences in the real spaces that the maps depict" (2015; https://www.lehman.edu/faculty/ guinazu/ciberletras/v33/smith.htm). In a way, the tragedy of Arturo Cova is to try to substitute the functions of the State in the rubber-producing areas. Smith pointed out the fact that Cova is infuriated when he realizes how bad the quality of maps produced by the central Government is. Because the maps are unreliable, Cova decided to avoid them. In the last entry of Cova's diary, "he sketches a 'croquis imaginado' of his location, which fails to lead rescuers to him and his party who have presumably been devoured by the jungle" (2015).

In a similar way, Cova tries to bring justice to colonos trapped in the jungle by denouncing the rubber-boom violence from their perspective as victims, survivors and witnesses. We believe that Rivera was not seeking the prosecution of those responsible of crimes against humanity. What Rivera had in mind was to substitute the State in the task of facilitating a broad acknowledgment of the crimes related to the rubber-boom period. For us, La vorágine was conceived as a fictional archive to fight against impunity.

According to Beckman (2013), Rivera was somehow in contact with the characteristic illegality or the rubber-producing areas when he visits the region: "Even though the boom had ended over a decade earlier, the border disputes provoked by the boom lived on. So too did stories, legends, and rumors about the violence unleashed by the rubber boom" (162). When Rivera was in the House of Representatives, he did his best to communicate the crimes in the jungle and the urgency of a decisive presence of the Colombian State in the same area. When he was ignored, he decided to write a novel to attain the same goal. Although the right to the truth did not start taking form until the 1970's in Latin America, it is clear to us that La vorágine was written in the same spirit. The novel also expresses Rivera's skepticism in the Colombian government's ability to enforce complete sovereignty across the national territory. In this sense, the novel is a fiction of distrust.

\section{Works Cited}

AGN. 1938. Cuestionario enviado por el Consejo Directivo de la VII Conferencia en Instrucción Pública a realizarse en Ginebra (Suiza). CO.AGN.SAA-II.22.14.109, Folios 199-201.

Anderson, Benedict. 2006. Imagined Communities. London: Verso.

Arocha, Alfonso. 2007. "Retórica testimonial entre verosimilitud y ficción en La vorágine." Revista Poligramas, no. $28: 129$.

Beckman, Ericka. 2013. Capital Fictions: The Literature of Latin America's Export Age. University of Minnesota Press.

Benso, Silvia. 1975. “«La vorágine»: una novela de relatos” Thesaurus, vol. XXX. no. 2: 271-290.

Chasteen, John Charles. 2003. "Ìntroduction." In Beyond Imagined Communities: Reading and Writing the Nation in Nineteenth-century Latin America, IX-XXV. Woodrow Wilson Center Press.

Chasteen, John Charles, and Sara Castro-Klarén. 2003. Beyond Imagined Communities: Reading and Writing the Nation in Nineteenth-century Latin America. Woodrow Wilson Center Press.

Ciorciari, John D., and Jesse M. Fransblau. 2014. "Hidden files: archival sharing, accountability, and the right to the truth." Columbia Human Rights Law Review 46 (1): 1-84.

CONADEP. 2016. Nunca más. EUDEBA.

Davis, Wade. 1996. One River: Explorations and Discoveries in the Amazon Rain Forest. New York: Simon \& Schuster.

French, Jennifer. 2005. Nature, Neo-colonialism, and the Spanish American Regional Writers. Dartmouth College Press.

González-Espitia, Juan Carlos. 2010. On the Dark Side of the Archive: Nation and Literature in Spanish America at the Turn of the Century. Bucknell University Press.

Grandin, Greg. 2009. Fordlandia: The Rise and Fall of Henry Ford's Forgotten Jungle City. New York: Metropolitan Books. 
Grillo, Max. 1925. “Segunda edición de 'La vorágine’.” El Gráfico: Bogotá, no. 765, 756-57.

Groome, Dermot. 2011. "The Right to Truth in the Fight Against Impunity.” Berkeley Journal of International Law 29 (1): 175-199.

Hardenburg, W. E. 2017. The Putumayo, the Devil's Paradise: Travels in the Peruvian Amazon Region and an Account of the Atrocities Committed Upon the Indians Therein. CreateSpace Independent Publishing Platform.

Hayner, Priscilla B. Unspeakable Truths 2e: Transitional Justice and the Challenge of Truth Commissions. Routledge, 2010.

---. 2011. Unspeakable truths: transitional justice and the challenge of truth commissions. Second edition. New York: Routledge is an imprint of the Taylor \& Francis Group.

IACHR. 2014. The Right to Truth in the Americas. Washington, D.C.: Inter-American Commission on Human Rights (IACHR).

ICRC. 1949a. "Geneva Convention: Rule 116. Accounting for the Dead.” https://ihl-databases.icrc.org/customary-ihl/eng/docs/ v1_rul_rule116.

. 1949b. "Geneva Convention: Rule 117. Accounting for Missing Persons.” https://ihl-databases.icrc.org/customaryihl/eng/docs/ v1_rul_rule117\#refFn_7218634_00003.

“Lacrimabili Statu (June 7, 1912) | PIUS X.” 2020. Accessed June 29. http://www.vatican.va/content/pius-x/en/encyclicals/ documents/hf_px_enc_07061912_lacrimabili-statu.html.

Lasso, Marixa. 2007. Myths of Harmony: Race and Republicanism during the Age of Revolution, Colombia 1795-1831. Pitt Latin American series Myths of harmony. Place of publication not identified: University of Pittsburgh Press.

Molina-Ochoa, Andrés, and Alfredo Duplat. 2021. "The Right to the Truth in the Colombian Conflict: Realities and Fiction." The Colombian Peace Agreement: A Multidisplinary Assessment. Routledge: forthcoming.

Molloy, Sylvia. 1987. "Contagio narrativo y gesticulación retórica en La vorágine.”

Revista Iberoamericana 53 (141): 745-766. Accessed June 28, 2020. http://revista-iberoamericana.pitt.edu/ojs/index.php/ Iberoamericana/article/view/4388.

Neale-Silva, Eduardo. 1960. Horizonte humano: Vida de josé eustasio rivera. Madison: U of Wisconsin P.

Nouzeilles, Gabriela. 2005. "Beyond Imagined Communities: Reading and Writing the Nation in Nineteenth-Century Latin America (review)." (Philadelphia) 73 (4): 514-517.

Ordóñez, Monserrat. 1995. “Introducción.” In La vorágine, 9-71. Madrid: Cátedra.

Paternoster, G. Sidney. 1913. The Lords of the Devil's Paradise. S. Paul \& Company.

Pérez Silva, Vicente. 1981. "Del libro de las polémicas: Luis Trigueros y José Eustasio Rivera.” Boletín Cultural y Bibliográfico 18 (01): 94-114. Accessed October 14, 2020. https://publicaciones.banrepcultural.org/index.php/ boletin_cultural/article/ view/3543.

Rivera, José Eustasio. 1924a. "El avance de los peruanos.” El Tiempo.

---. 1924b. “J. E. R. Habla sobre la invasión peruana al putumayo y caquetá.” El Espectador.

---. 1924c. "La concesión arana y los asuntos con venezuela.” El Espectador.

---. 1924d. "La penetraciones peuanas en el Caquetá.” El Tiempo. 
Sanders, James E. 2004. Contentious Republicans: Popular Politics, Race, and Class in Nineteenth-century Colombia. Durham: Duke University Press.

Skaar, Elin, Jemima García-Godos, and Cath Collins, eds. 2016. Transitional Juice in Latin America. New York: Routledge.

Skinner, Lee J. 2001. "Martyrs of Miscegenation: Racial and National Identities in Nineteenth-century Mexico." Hispanófila, no. $132: 25-42$.

Smith, Amanda M. 2015. "The Vortex and the Map: Cartographic Illusion and Counter-Mapping in La vorágine (i)." Ciberletras 33:23. Accessed October 13, 2020.

Sommer, Doris. 1991. Foundational fictions: The National Fictions of Latin America. Berkeley: U of California P.

Thomson, Norman. 2019. The Putumayo Red Book. Creative Media Partners, LLC.

UNDP. 2013. Excecutive sumary: Human development report for latin america 2013-2014. New York: United Nations Development Programme (UNDP).

Vargas Llosa, Mario. 1972. "En torno a la nueva novela latinoamericana." Revista de la Universidad de Puerto Rico 1: 129-40.

"What are archives? | International Council on Archives (ICA)." 2020. Accessed October 12. https://www.ica.org/en/whatarchive.

\section{Notes}

1. We follow the definition of archive used by the International Council on Archives (ICA): "Archives are the documentary by-product of human activity retained for their long-term value." (2020)

2. Nunca más: Informe de la Comisión sobre la Desaparición de Personas, a report written in Argentina in 1984 by Comisión Nacional sobre la Desaparición de Personas (CONADEP) is a significant example of the results of a truth commission. The report revealed the existence of illegal detention centers as well as conditions and methods of torture used during the military dictatorship between 1976 and 1983. According to Hayner, Nunca más "was an immediate best-seller: 40,000 copies were sold on the first day of its release, 150,000 copies in the first eight weeks. It has now been reprinted well over twenty times, and by 2007 had sold more than 500,000 copies, standing as one of Argentina's best-selling books ever" $(2011,46)$.

3. One of the few literary critics in Bogota at that time, Max Grillo, even compared La vorágine with Tolstoy's War and Peace, and to another significant example of what we understand as fiction of distrust in Brazil, Os Sertões by Euclides da Cunha, $(1925,754)$.

4. Geography plays an important role in this context. Colombia is $33 \%$ bigger than Texas and has a rough topography. The pronounced differences in elevation caused by the mountains of the Andes that form three parallel ranges in that country, with peaks as high as 17,602 ft, are important to understand why the majority of Colombians never experienced first-hand the regions that are close to the jungles.

5. This was, in fact, the second Peruvian invasion. The first happened in 1911 and it is known as Conflicto de La Pedrera.

6. On April 15, 1924, Rivera organized a patriotic rally at the City Hall of Neiva, his hometown, to denounce the lack of presence of the Colombian State in the rubber-producing areas. The event was so well attended that the organizers, Rivera and Reynaldo Matiz, had to find a bigger location to accommodate the audience (Neale-Silva 1960, 278).

7. According to Jennifer French, "in 1907 Arana's businesses became multinational: it registered on the London Stock Exchange, and received more than one million pounds sterling in investment" $(2005,113)$. 